\title{
2',6'-Dimethylphenylalanine: A Useful Aromatic Amino Acid Surrogate for Tyr or Phe Residue in Opioid Peptides
}

\author{
Yusuke Sasaki and Akihiro Ambo \\ Department of Biochemistry, Tohoku Pharmaceutical University, 4-4-1 Komatsushima, Aoba-ku, Sendai 981-8558, Japan \\ Correspondence should be addressed to Yusuke Sasaki, ysasaki@tohoku-pharm.ac.jp
}

Received 31 January 2012; Revised 15 March 2012; Accepted 18 March 2012

Academic Editor: Yoshio Okada

Copyright (C 2012 Y. Sasaki and A. Ambo. This is an open access article distributed under the Creative Commons Attribution License, which permits unrestricted use, distribution, and reproduction in any medium, provided the original work is properly cited.

\begin{abstract}
Two aromatic amino acids, $\mathrm{Tyr}^{1}$ and $\mathrm{Phe}^{3}$ or $\mathrm{Phe}^{4}$, are important structural elements in opioid peptides because they interact with opioid receptors. The usefulness of an artificial amino acid residue $2^{\prime}, 6^{\prime}$-dimethylphenylalanine (Dmp) was investigated as an aromatic amino acid surrogate for several opioid peptides, including enkephalin, dermorphin, deltorphin, endomorphin, dynorphin A, and nociceptin peptides. In most peptides, substitutions of Phe ${ }^{3}$ by a Dmp residue produced analogs with improved receptor-binding affinity and selectivity, while the same substitution of Phe ${ }^{4}$ induced markedly reduced receptor affinity and selectivity. Interestingly, replacement of $\mathrm{Tyr}^{1}$ by Dmp produced analogs with unexpectedly high affinity or produced only a slight drop in receptor affinity and bioactivity for most peptides. Thus, Dmp is also a useful surrogate for the N-terminal Tyr residue in opioid peptides despite the lack of a phenolic hydroxyl group, which is considered necessary for opioid activity. The Dmp ${ }^{1}-$ substituted analogs are superior to $2^{\prime}, 6^{\prime}$-dimethyltyrosine $(\mathrm{Dmt})^{1}$-substituted analogs for high receptor selectivity since the latter generally have poor receptor selectivity. Thus, Dmp is very useful as an aromatic amino acid surrogate in opioid peptides and may be useful for developing other novel peptide mimetics with high receptor specificity.
\end{abstract}

\section{Introduction}

Three major types of opioid receptors, $\mu, \delta$, and $\kappa$, have been cloned and assigned to the superfamily of rhodopsinlike G-protein-coupled receptors [1-3]. The $\mu$-receptors are involved in supraspinal analgesia, respiratory depression, euphoria, sedation, decreased gastrointestinal motility, and physical dependence [4]. The $\delta$-receptors appear to affect cardiovascular function, contribute to analgesia, and cause changes in affective behavior [4]. The $\kappa$-receptors are responsible for spinal analgesia, miosis, a modest degree of sedation, and some respiratory depression [4]. In vivo, opioid peptides exert pharmacological actions via the opioid receptors. Enkephalins (Tyr-Gly-Gly-Phe-Leu/Met) [5] and endomorphins (Tyr-Pro-Phe/Trp-Phe- $\mathrm{NH}_{2}$ ) [6] are endogenous ligands for the $\delta$ - and $\mu$-opioid receptors, respectively. Dynorphin A (DYN: Tyr-Gly-Gly-Phe-Leu-Arg-Arg-Ile-Arg-ProLys-Leu-Lys-Trp-Asp-Asn-Gln) is the endogenous ligand of the $\kappa$-opioid receptor [7]. Dermorphin (DM, Tyr-D-AlaPhe-Gly-Tyr-Pro-Ser- $\mathrm{NH}_{2}$ ) [8] and [D-Ala ${ }^{2}$ deltorphin II
(DT, Tyr-D-Ala-Phe-Glu-Val-Val-Gly- $\mathrm{NH}_{2}$ ) [9] are naturally occurring opioid peptides isolated from South American frogs and possess high selectivity toward $\mu$ - and $\delta$-opioid receptors, respectively.

A fourth cloned member of the opioid-receptor family is the opioid receptor-like 1 (ORL1) receptor that shares high sequence homology with traditional opioid receptors [10]. The heptadecapeptide nociceptin (NOC) [11] or orphanin FQ [12] (NOC: Phe-Gly-Gly-Phe-Thr-Gly-AlaArg-Lys-Ser-Ala-Arg-Lys-Leu-Ala-Asn-Gln) was discovered as an endogenous ligand for the ORL1 receptor. NOC and DYN have a similar structural feature including the $\mathrm{N}$ terminal tetrapeptide sequence Phe-Gly-Gly-Phe in NOC and Tyr-Gly-Gly-Phe in DYN and the existence of basic residues, although with different distributions, at the $\mathrm{C}$ terminal. Despite the sequence homology, NOC and DYN have different pharmacological profiles [13, 14]. NOC possesses hyperalgesia and allodynia activity when applied supraspinally at low doses, while spinal delivery of NOC causes analgesia at high doses $[11,13-15]$. Two aromatic 
amino acids, Phe $e^{1,4}$ at the N-terminal of NOC $[14,16,17]$ and $\mathrm{Tyr}^{1}$ and $\mathrm{Phe}^{4}$ in DYN $[18,19]$, are important residues required for receptor binding and/or biological activity and are needed for discriminating between them. In particular, the presence of $\mathrm{N}$-terminal $\mathrm{Phe}^{1}$ is indispensable for NOC activity, and the C-terminal half of NOC may serve as a domain that prevents binding to opioid receptors [20].

In the field of opioid peptides, a number of synthetic analogs have been prepared based on structure-activity studies focusing on the aromatic amino acids $\mathrm{Tyr}^{1}$ and either Phe $\mathrm{P}^{3}$ or $\mathrm{Phe}^{4}$, which are important structural elements that interact with opioid receptors [21]. Among these, the most active analogs were those that substituted $2^{\prime}, 6^{\prime}$ dimethyltyrosine (Dmt) for $\mathrm{Tyr}^{1}$, which vastly improved opioid receptor binding affinity [22-36]. Structure-activity relation studies of opioid peptides using Dmt revealed that introduction of $\mathrm{Dmt}^{1}$ could improve receptor affinity and opioid potency. In addition, combination of Dmt with 1,2,3,4-tetraisoquinoline-3-carboxylic acid (Tic), Dmt-Tic pharmacophore, also produced potent $\delta$-selective antagonists, including Dmt-Tic-OH $[31,32], \mathrm{N}^{\prime} \mathrm{N}^{\prime}$-diMeDmt-Tic$\mathrm{OH}$ [33], DIPP-NH$H_{2}$ [34], and DIPP [ $\Psi$ ] [35]. The 2,6dimethylation of the aromatic moiety in Leu-enkephalin (ENK) imparted high enzymatic stability to the peptide [36]. These findings prompted a study to modify a Phe aromatic moiety at position 3 or 4 of opioid peptides through 2,6-dimethylation because no derivatives with phenyl ringmethylated Phe incorporated into opioid peptides have been reported, only other biologically active peptides have been prepared $[37,38]$. The usefulness of incorporating the artificial aromatic amino acid, 2' $6^{\prime}$-dimethylphenylalanine (Dmp) (Figure 1) as an aromatic amino acid surrogate in opioid peptides to develop opioid ligands specific for opioid receptors was investigated. This paper includes all studies that involved substitution of the Dmp residue into opioid peptides reported in the last decade.

\section{Preparation of $2^{\prime}, 6^{\prime}$-Dimethylphenylalanine (Dmp)}

Initially, Dmp and D-Dmp were synthesized by the route illustrated in Scheme 1 [39]. Commercially available 1 reacted with sodium trimethyl stannane according to the method of Yamamoto et al. [40], followed by reaction with iodine according to the method of Ohno et al. [41]. A key intermediate, 2-iodo- $m$-xylene (3), reacted with methyl 2-acetamidoacrylate by Dygos' method [42], which led to 4 , followed by saponification to yield $\mathbf{5}$. Catalytic hydrogenation of 5 yielded racemic Ac-Dmp (6). For optical resolution, 6 was converted to its dipeptide derivatives, AcDL-Dmp-Arg-OMe (7), which were easily separated into diastereoisomers by preparative HPLC. Acid hydrolysis and neutralization of each isomer yielded Dmp (8) and D-Dmp (9). The L and D configurations were determined using L-amino acid oxydase according to a method reported by Toth et al. [43].

In addition, Li et al. prepared Dmp using the asymmetric synthetic method of Dygos et al. [42], which was applied to the endomorphin analogs [44].

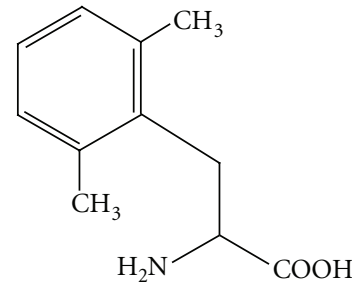

Figure 1: Structure of $2^{\prime}, 6^{\prime}$-dimethylphenylalanine (Dmp).

\section{Dmp Replacement of Phenylalanine Residue at Position 3 or 4 in Opioid Peptides}

The usefulness of Dmp was first investigated as a surrogate for $\mathrm{Phe}^{4}$ in ENK analogs [39]. The receptor-binding affinities of synthetic analogs were determined using rat brain, as previously reported [45]. As shown in Table 1, replacement of Phe ${ }^{4}$ in ENK by Dmp led to analog 10 with $\mu$-receptor affinity comparable to ENK, but with approximately 12fold reduction in $\delta$-receptor affinity, resulting in a change of preferential receptor from $\delta$ to $\mu$. The D-Dmp replacement of ENK (11) induced significant reduction in binding affinity for both receptors. Combined replacement of $\mathrm{Dmp}^{4}$ and $\mathrm{Dmt}^{1}$ produced $\mathbf{1 2}$ with markedly improved affinities for both receptors, 40- and 110-fold greater in affinity than 10 for the $\mu$ - and $\delta$-receptors, respectively. However, 12 possessed 5 -fold lower affinity than that of $\left[\mathrm{Dmt}^{1}\right] \mathrm{ENK}$ for both receptors, possibly due to slight changes in the active conformation by simultaneous dimethylation of two aromatic moieties. D-Dmp ${ }^{4}$ replacement of $\mathbf{1 2}$ led to 13, which retained $\mu$ affinity equivalent to that of ENK and modest $\delta$ affinity, demonstrating the effectiveness of Dmt ${ }^{1}$ replacement for maintaining high receptor affinity. In vitro biological activity of ENK analogs was evaluated using isolated guinea pig ileum (GPI) and mouse vas deferens (MVD) tissue samples, as previously reported [46]. The GPI tissue contains predominantly $\mu$-receptors, while MVD tissue contains $\delta$-receptors [47]. As shown in Table 1 , compound 10 possessed 8 - and 30-fold lower activity compared to ENK in the GPI and MVD assays, respectively. In contrast, 11 was devoid of activity in both assays, as expected from the binding data. Analog 13 also lacked activity in both assays, even though this analog showed potent $\mu$ affinity and modest $\delta$ affinity. This analog turned out to be a potent $\mu$-antagonist and a weak $\delta$-antagonist. The $\mathrm{pA}_{2}$ values of 13 were 6.90 against EM2 as a $\mu$ agonist in the GPI assay and 5.57 against DT as a $\delta$ agonist, in the MVD assay. The results of 13 are in line with observations that Dmt-D-Phe- $\mathrm{NH}_{2}$ and its Cterminally extended analog are $\mu$-receptor antagonists [48].

Effects of Dmp substitution for phenylalanine at position 3 or position 4 in EM2 were examined (Table 1) [49]. The EM2 possessed great affinity and selectivity for the $\mu$ receptor. Interestingly, Dmp substitution for $\mathrm{Phe}^{3}$ in EM2 (14) produced a compound with 10 -fold greater affinity than that of EM2 for both the $\mu$ - and $\delta$-receptors and still retained high $\mu$-receptor selectivity comparable to that of EM2. The Dmp substitution of Phe in position 4 (16), however, resulted 


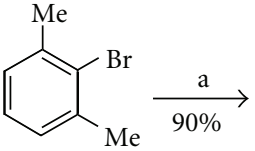

1

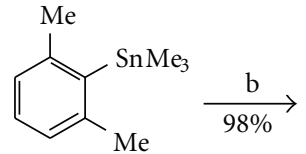

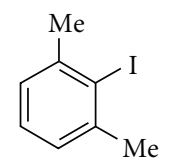
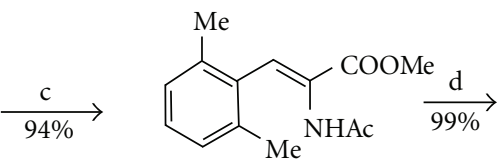

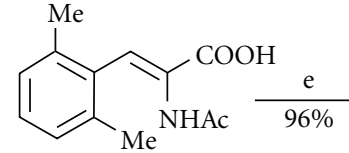

5

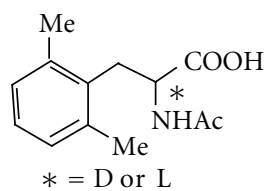

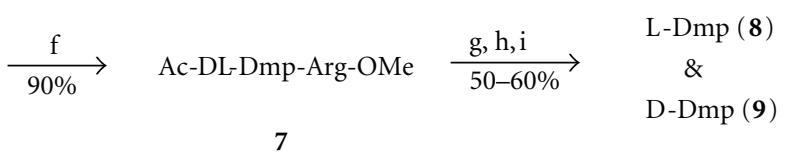

Scheme 1: Synthetic route to L-Dmp and D-Dmp, (a) $\mathrm{Me}_{3} \mathrm{SnNa}$, DME, ice-salt bath, $2 \mathrm{~h}$; (b) $\mathrm{I}_{2} / \mathrm{THF}, \mathrm{rt}, 3 \mathrm{~h}$; (c) methyl 2acetamidoacrylate $/ \mathrm{Pd}(\mathrm{OAc})_{2} / \mathrm{Et}_{3} \mathrm{~N} / \mathrm{MeCN},\left(2-\mathrm{MeC}_{6} \mathrm{H}_{4}\right)_{3} \mathrm{P}$, reflux, $24 \mathrm{~h}$; (d) $1 \mathrm{M} \mathrm{NaOH} /$ dioxane, rt, $2 \mathrm{~h} ;(\mathrm{e}) \mathrm{H}_{2}\left(4 \mathrm{kgf} / \mathrm{cm}^{2}\right) / 10 \% \mathrm{Pd}-\mathrm{C} / \mathrm{AcOH}$, $70^{\circ} \mathrm{C}, 48 \mathrm{~h}$; (f) $\mathrm{HCl} \cdot \mathrm{Arg}-\mathrm{OMe} / \mathrm{Et}_{3} \mathrm{~N} / \mathrm{DCC} / \mathrm{HOBt} / \mathrm{DMF}, 0^{\circ} \mathrm{C}$ to rt, $5 \mathrm{~h}$; (g) preparative HPLC; (h) concd $\mathrm{HCl}, \mathrm{reflux}, 8 \mathrm{~h}$; (i) pH $4-6 / \mathrm{H}_{2} \mathrm{O}$.

in a 23 -fold decrease in $\mu$ affinity and a slight increase in $\delta$ affinity, resulting in a significant decrease in $\mu$-receptor selectivity. The introduction of D-Dmp at either position 3 or 4 (15 or 17 , resp.) resulted in a significant decrease in $\mu$ affinity and selectivity, which agreed with the results from D-Phe-replaced analogs [50]. Analog 15 retained moderate $\mu$ affinity with a $K$ i value of $2.4 \mathrm{nM}$, whereas 16 and 17 exhibited significantly decreased $\mu$ affinity. In the in vitro assay, 14 exhibited considerably greater GPI potency than EM2 as expected; however, this analog exhibited more potent MVD activity than that expected from $\delta$-binding. This may be due to $\mu$-receptors, which coexist in the MVD tissues, because the high MVD potency was strongly inhibited by the specific $\mu$-receptor antagonist CTAP [51]. A similar trend was observed with other $\mu$-receptor ligands $[52,53]$. These results suggest that Dmp substitution of $\mathrm{Phe}^{3}$ of EM2 promotes $\mu$ receptor specificity and that $\mathrm{Phe}^{3}$ is more amenable to Dmp or its D-isomer substitution compared to $\mathrm{Phe}^{4}$.

Use of Dmp as a Phe surrogate in DM and DT heptapeptides was also examined [52]. Replacement of Phe by Dmp in the $\mu$-specific ligand DM (18) induced a significant increase (170-fold) in $\mu$ affinity and only a modest increase in $\delta$ affinity, resulting in marked improvement of $\mu$-receptor selectivity. The D-Dmp ${ }^{3}$ replacement (19), however, resulted in marked decrease in both $\mu$ and $\delta$ affinities. Interestingly, the Dmp ${ }^{3}$ replacement in $\delta$-specific ligand DT produced 20 with a 22 -fold increase in $\delta$ affinity and a 3 -fold decrease in $\mu$ affinity, resulting in a 75 -fold increase in $\delta$-receptor selectivity with unprecedented $\delta$-receptor selectivity $(\mu / \delta=$ $1,045,714)$. The configurational inversion of Dmp in DT (21) was detrimental to $\delta$-receptor selectivity. Results of the in vitro bioassay of these analogs showed that 18 exhibited a slight increase in GPI potency and a greater increase in MVD potency, while 19 showed marked decreases in both assays as expected from binding affinities. The discrepancy between the degree of increase (3-fold) in the GPI assay observed with 18 and the $\mu$-binding data (170-fold) may be due to differences in $\mu$-receptors in the brain and peripheral tissues. The Dmp ${ }^{3}$-substituted DT analog 20 showed markedly increased MVD potency, resulting in a very high GPI/MVD ratio of 304,772. As expected, D-Dmp ${ }^{3}$-substituted DT (21) possessed very low MVD potency. Analogs 18 and 20 are among the most potent and selective ligands for $\mu$ - and $\delta$ opioid receptors, respectively, and therefore are candidates for investigations of opioid systems.

A dermorphin tetrapeptide analog, Tyr-D-Arg-Phe$\beta$ Ala- $\mathrm{NH}_{2}$ (YRFB), is a highly potent and selective ligand for the $\mu$-opioid receptor [53]. The usefulness of Dmp replacement for $\mathrm{Phe}^{3}$ in this tetrapeptide was examined [54]. Substituting Dmp for $\mathrm{Phe}^{3}$ in YRFB (22) induced a 5 -fold increase in $\mu$-receptor affinity without significant change in $\delta$-receptor affinity, as compared to the parent peptide. Results from the GPI assay using this compound coincided well with the binding data, but a slight increase in activity in the MVD assay was found. As shown in Table 2, low $K_{\mathrm{e}}$ values for the $\mu$-antagonist CTAP and high $K_{\mathrm{e}}$ values for the $\delta$ antagonist $\mathrm{N}, \mathrm{N}(\mathrm{Me})_{2}$ Dmt-Tic-OH [33], against 22 suggest that the GPI activity of these analogs occurred mainly via the $\mu$-opioid receptor. Analog 22 was also tested for analgesic activity in the formalin test in mice and was compared to results for YRFB and morphine. As shown in Table 3, subcutaneous injection of this analog produced dose-dependent antinociceptive activity in mice in both the first and second phases. Its analgesic activity was approximately 40- and 70-fold more potent than that of morphine in the first and second phases, respectively. These results indicate that Dmp is effective as a Phe surrogate for improving functional activity and maintaining $\mu$-selectivity 
[52]. In contrast, [D-Dmp ${ }^{3}$ ] YRFB (23) exhibited $\mu$-receptor affinity similar to the parent peptide, but it exhibited an order of magnitude lower GPI potency.

Next, the effect of Dmp replacement of N-terminal aromatic residues in DYN and NOC was compared [55]. Six analogs (26-31) containing Dmp in position 1 and/or 4 of DYN (1-13)- $\mathrm{NH}_{2}$ and NOC (1-13)- $\mathrm{NH}_{2}$ were synthesized and tested for their binding affinity to opioid receptors derived from rat ( $\mu$ - and $\delta$-receptors) or guinea pig ( $\kappa$ receptor) brains and to membrane preparations derived from HEK293 cells expressing human ORL-1 receptor. Results are shown in Table 4. In a series of DYN(1-13)- $\mathrm{NH}_{2}$ analogs, the parent peptide DYN(1-13)- $\mathrm{NH}_{2}$ showed high affinity toward $\kappa$-, $\mu$-, and $\delta$-opioid receptors with $\kappa$-receptor selectivity, that is, an $\mathrm{IC}_{50}$ ratio of $1 / 15.6 / 40.1$ and significantly low affinity toward the ORL1 receptor, similar to an observation of intact DYN $[11,20] . \mathrm{Dmp}^{4}$ replacement afforded 26, which had greater $\kappa$-opioid receptor affinity than that of the parent peptide and significantly improved $\kappa$-receptor selectivity $\left(\mathrm{IC}_{50}\right.$ ratios: $1(\kappa) / 509(\mu) / 21159(\delta)$ versus DYN(113) $\left.-\mathrm{NH}_{2}, 1(\kappa) / 15.6(\mu) / 40.1(\delta)\right)$. Compound 26 exhibited an order of magnitude decrease in affinity, indicating that the $\mathrm{Dmp}^{4}$ modification in DYN peptides is detrimental to ORL1-receptor affinity, as was observed with NOC peptides. NOC (1-13)- $\mathrm{NH}_{2}$ possessed high ORL1 receptor affinity and poor affinity for $\kappa-, \mu$-, and $\delta$-opioid receptors. The Dmp ${ }^{4}$ NOC analog (29) showed a 70-fold decrease in ORL1 affinity without significant changes in affinity toward the opioid receptors. These results indicate the critical importance of the $\mathrm{Phe}^{4}$ residue for interactions with the ORL1 receptor. A Dmp residue at this position appears to influence the conformation of the NOC peptide by $2^{\prime}, 6^{\prime}$-dimethylation of the Dmp side chain aromatic moiety. This occurs because, according to the proposed model of the ORL1 receptor and its complex with NOC, the $\mathrm{Phe}^{4}$ residue of NOC located at a hydrophobic pocket in a cavity formed by TM helices $3,5,6$, and 7 and the Phe ${ }^{4}$ side chain interact with $\mathrm{Phe}^{220}$ of the ORL1 receptor through an edge-face interaction [56]. Two methyl groups on $\mathrm{Dmp}^{4}$ may interfere with the receptor interaction due to a reduction in conformational flexibility and/or enhanced lipophilicity. To further examine the usefulness of Dmp-containing DYN peptides as $\kappa$ opioid receptor ligands, the in vitro bioactivity of DYN peptides was determined using the GPI assay (Table 5). Contrary to the high $\kappa$-opioid receptor-binding profile, 26 exhibited unexpectedly low GPI potency, which was one order of magnitude lower than the parent peptides. Low $K_{\mathrm{e}}$ values for the $\kappa$-receptor antagonist and high $K_{\mathrm{e}}$ values for the $\mu$ - and $\delta$-antagonists of $\mathbf{2 6}$ suggest that the GPI activity of these analogs occurred mainly via the $\kappa$-opioid receptor.

\section{Dmp Replacement of N-Terminal Tyr Residue in Opioid Peptides}

The usefulness of $\mathrm{Dmp}^{1}$ substitution for $\mathrm{Tyr}^{1}$ in the $\delta$ opioid receptor-selective ligands, ENK and DT, and the $\mu$ opioid receptor-selective ligands, EM2 and YRFB, has been investigated $[49,53,57]$. Results of receptor-binding and in vitro assays are shown in Table 6 . The replacement of Tyr ${ }^{1}$ by Dmp in ENK led to 32, which possessed similar receptor affinity and selectivity as ENK, whereas $\mathrm{Dmt}^{1}$ replacement produced marked increases in both $\mu$ and $\delta$ affinities but did not increase receptor selectivity. Replacement of $\mathrm{Phe}^{1}$ in ENK (33) decreased the affinity by 50 - and 70-fold at the $\delta$ - and $\mu$-receptors, respectively. Replacement of $\operatorname{Tyr}^{1}$ by Dmp in DT (34) markedly decreased the binding affinity and selectivity toward the $\delta$-receptor. Introduction of the inverse configuration at this position (35) markedly reduced $\delta$ affinity and selectivity. In contrast, [Dmt $\left.{ }^{1}\right] \mathrm{DT}(36)$ possessed a 50 -fold increase in $\delta$ affinity and a 1200 -fold increase in $\mu$ affinity, resulting in substantial reduction in $\delta$-receptor selectivity, which agrees with previous results [28]. $\left[\mathrm{Phe}^{1}\right] \mathrm{DT}$ (37) retained significant $\delta$ affinity and good $\delta$ selectivity, similar to the results for $\left[\mathrm{Phe}^{1}\right]$ deltorphin I [58]. Analog 32 possessed lower MVD and GPI potency compared to ENK but showed significant MVD potency and GPI/MVD selectivity in agreement with the binding data. Analog 34 exhibited 2-fold greater potency for MVD and a greater GPI/MVD ratio compared to DT (selectivity ratio: 14,835 versus 9342) or [ $\left.\mathrm{Dmt}^{1}\right] \mathrm{DT}$ (36) (selectivity ratio: 14,835 versus 1700). The [ $\left.\mathrm{Phe}^{1}\right] \mathrm{DT}$ (37) exhibited a 20 -fold decrease in MVD potency compared to DT but retained significant potency and MVD specificity. These results demonstrate that the Dmp ${ }^{1}$ peptide is superior to the corresponding Dmt ${ }^{1}$ peptide in receptor selectivity because the latter generally possesses poor receptor selectivity.

In EM2 analogs, replacement of $\mathrm{Tyr}^{1}$ by Dmp led to 38, which showed a 4 -fold reduction, retaining significant $\mu$ affinity. Note that 38 retained high potency for $\mu$-receptors despite the lack of a phenolic hydroxyl group at the $\mathrm{N}$ terminal, which agreed with results for YRFB analogs [53]. The D-Dmp ${ }^{1}$ - or Phe ${ }^{1}$-substituted analogs of EM2 (39 and 40, resp.) showed a significant decrease in GPI potency, which was expected from the binding affinity. In contrast, 39 and $\mathbf{4 0}$ were more than 100 -fold less potent than EM2. Results from analog 38 supported the observation that a Dmp residue can mimic the $\mathrm{N}$-terminal Tyr of opioid peptides [53].

Replacing Tyr with Dmp at position 1 in YRFB (24) produced greater $\mu$ affinity and considerably lower $\delta$ affinity compared to YRFB and improved $\mu$-receptor selectivity by 15 -fold. This compound, however, showed slightly lower GPI and MVD potency compared to YRFB. The D-Dmp substitution for $\mathrm{Tyr}^{1}$ (41) markedly reduced affinities for both receptors and for in vitro biological activity, suggesting that the L-configuration at this position is crucial for receptor interactions. The dual substitutions of Dmp for the aromatic amino acids at positions 1 and 3 produced 25 with binding affinity and selectivity for the $\mu$-receptor that were slightly improved relative to those of $\mathbf{2 2}$ or $\mathbf{2 4}$. This analog also showed slightly greater GPI potency than YRFB. As shown in Table 2, the low $K_{\mathrm{e}}$ value found for the $\mu$-receptor selective antagonist CTAP in the GPI assay demonstrated inhibition of the high activity of $\mathrm{Dmp}^{1}$-containing analogs (24 and 25 ) and suggests that the activity is mediated via $\mu$-opioid receptors. The low $K_{\mathrm{e}}$ values for CTAP in the MVD assay 


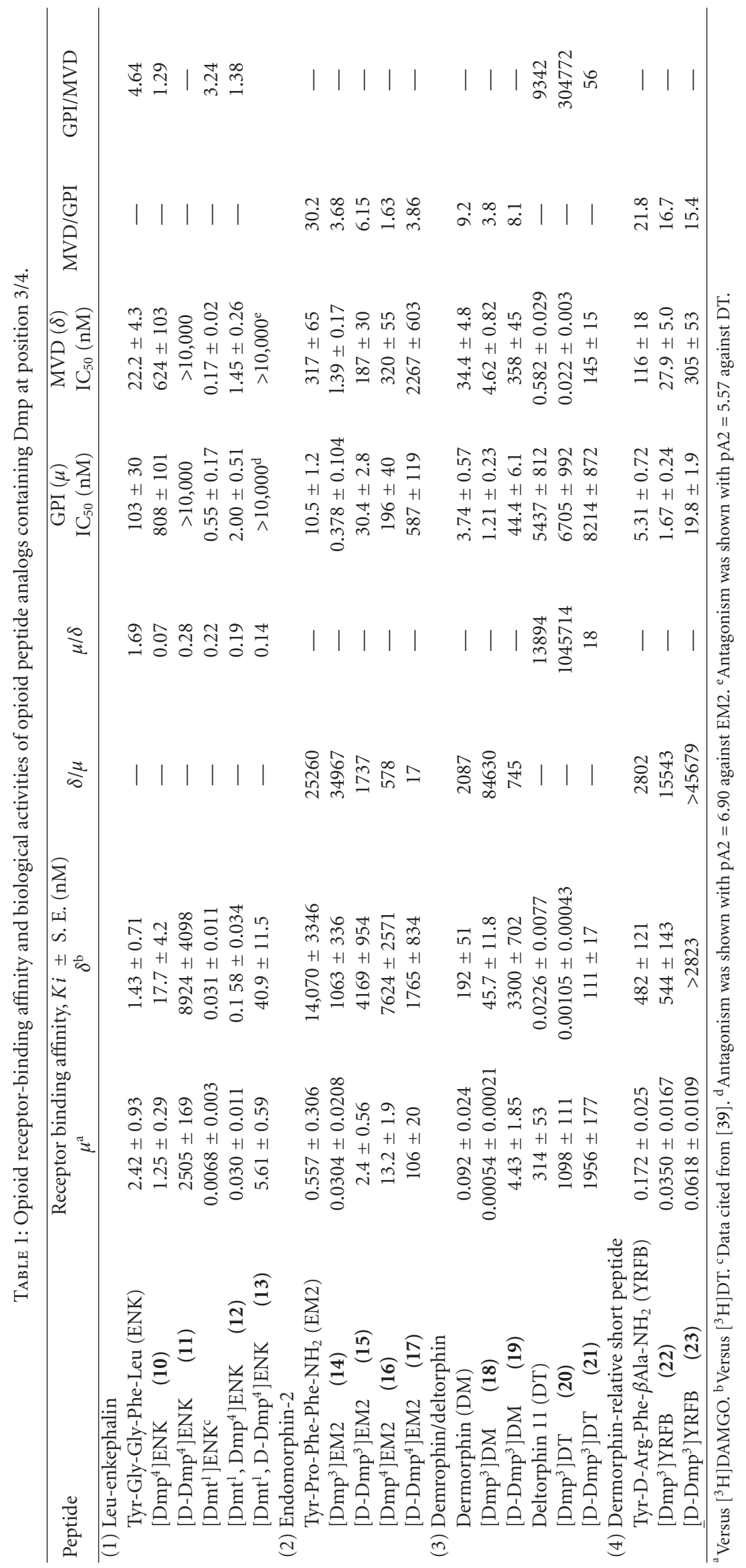


TABLE 2: $K_{\mathrm{e}}$ values of opioid receptor antagonists against Dmpcontaining YRFB analogs in the GPI and MVD assays.

\begin{tabular}{|c|c|c|c|c|}
\hline \multirow{3}{*}{ Peptides } & \multicolumn{4}{|c|}{$K_{\mathrm{e}}(\mathrm{nM})$} \\
\hline & & GPI & & MVD \\
\hline & & CTAP & CTAP & $\mathrm{N}, \mathrm{N}(\mathrm{Me})_{2}$ Dmt-Tic-OH \\
\hline$\left[\mathrm{Dmp}^{3}\right] \mathrm{YRFB}$ & (22) & 22.7 & 11.4 & $>1000$ \\
\hline$\left[\mathrm{Dmp}^{1}\right] \mathrm{YRFB}$ & $(24)$ & 25.1 & 13.4 & $>1000$ \\
\hline$\left[\mathrm{Dmp}^{1,3}\right] \mathrm{YRFB}$ & $(25)$ & 21.3 & 10.2 & $>1000$ \\
\hline YRFB & & 26.8 & 21.2 & $>1000$ \\
\hline$\left[\mathrm{Dmt}^{1}\right] \mathrm{YRFB}^{\mathrm{b}}$ & & 85.5 & 7.89 & 192 \\
\hline DT & & $\mathrm{NT}^{\mathrm{a}}$ & $>1000$ & 0.64 \\
\hline
\end{tabular}

${ }^{a}$ Not tested.

TABle 3: Antinociceptive activities of Dmp-containing YRFB analogs after subcutaneous injection in the formalin test.

\begin{tabular}{|c|c|c|c|c|}
\hline \multirow{2}{*}{ Peptides } & & & \multicolumn{2}{|c|}{$\mathrm{ED}_{50}(95 \% \text { C. L. })^{\mathrm{a}}, \mathrm{nmol} / \mathrm{kg}$} \\
\hline & & & First phase & Second phase \\
\hline$\left[\mathrm{Dmp}^{3}\right] \mathrm{YRFB}$ & (22) & 98.6 & $(26.7-364)$ & $113 \quad(48.6-264)$ \\
\hline$\left[\mathrm{Dmp}^{1}\right]$ YRFB & (24) & 1946 & $(1026-3691)$ & (1199-1950) \\
\hline YRFB & & 628 & $(364-1280)$ & $(378-700)$ \\
\hline Morphine & & 3811 & $(2921-4973)$ & $(4058-13198)$ \\
\hline
\end{tabular}

${ }^{\mathrm{a}} \mathrm{ED}_{50}$ values and $95 \%$ confidence limits.

indicate its inhibition of the analogs MVD activity, but the $\delta$-receptor selective antagonist $\mathrm{N}, \mathrm{N}(\mathrm{Me})_{2} \mathrm{Dmt}-\mathrm{Tic}-\mathrm{OH}$ did not inhibit this activity. This result may be due to $\mu$-receptor cooccurring with the $\delta$-receptor in MVD tissue. Analogs 24 and 25 retained high $\mu$-receptor affinity and potent GPI activity despite the lack of a phenolic hydroxyl group in the side chain of the $\mathrm{N}$-terminal residue, which is considered crucial for binding and activating opioid receptors. However, some cyclic somatostatin- or DPDPE-based analogs possess high affinity for and/or potency toward the $\mu$-receptor despite the absence of this group at the $\mathrm{N}$-terminal residue [59-63]. Analogs 24 and 25 are examples of linear peptides lacking an $\mathrm{N}$-terminal phenolic hydroxyl group but possess high opioid activity. The present results support reports of the interactions of cyclic compounds that indicate the Tyr hydroxyl moiety at the $\mathrm{N}$-terminal residue of opioid peptides is not an absolute requirement for interaction with opioid receptors and signal transduction. Because replacing the Tyr ${ }^{1}$ residue with Phe (42) drastically reduced $\mu$-receptor affinity and GPI potency, effects of Dmp substitution on receptor interactions are attributable mainly to enhanced hydrophobicity and/or increased conformational stability of the side chain of the aromatic ring. The basic functional group of the D-Arg residue at position 2 may also be responsible for the potent receptor interaction because the affinity of $\mathbf{4 1}$ and $\mathbf{4 2}$ was very low, but significant affinity for the $\mu$-receptor was retained. In addition, the Dmt ${ }^{1}$-substituted YRFB exhibited great affinity for both the $\mu$ - and $\delta$-receptors, which often resulted in low receptor selectivity. Such trends have also been observed with other Dmt ${ }^{1}$-substituted opioid peptides $[39,64,65]$. In contrast, substitution of $\mathrm{Dmp}^{1}$ for $\mathrm{Tyr}^{1}$ improved $\mu$-receptor selectivity exclusively, a result distinct from the effects of $\mathrm{Dmt}^{1}$ substitution. In the formalin test in mice, analog 24 also exhibited approximately 3 -fold (first phase) and 5-fold (second phase) greater potency than that of morphine, but the potencies were approximately 3 -fold less than those of YRFB. The analgesic potencies of these analogs correlated well with their GPI potencies.

In a series of DYN(1-13)- $\mathrm{NH}_{2}$ analogs, $\mathrm{Dmp}^{1}$ replacement afforded 27 with greater $\kappa$-opioid receptor affinity than that of the parent peptide; Dmp ${ }^{1}$ replacement also significantly improved $\kappa$-receptor selectivity $\left(\mathrm{IC}_{50}\right.$ ratios: 27, $1(\kappa) / 293(\mu) / 180(\delta)$ versus $\mathrm{DYN}(1-13)$ $\left.\mathrm{NH}_{2}, 1(\kappa) / 15.6(\mu) / 40.1(\delta)\right)$. These results support our recent finding that Dmp is an effective surrogate for the Tyr ${ }^{1}$ residue in opioid peptides [49, 53, 57]. Analog 27, however, exhibited low GPI potency two orders of magnitude less than DYN(113) $-\mathrm{NH}_{2}$. Low $K_{\mathrm{e}}$ values for the $\kappa$-receptor antagonist norBNI suggests that its GPI activity occurred mainly via the $\kappa$-opioid receptor, similar to the observations for $\mathbf{2 6}$. The discrepancy between $\kappa$-opioid receptor binding and GPI potency observed with 27 can be attributed to the lack of hydroxyl side chains on the $\mathrm{N}$-terminal residue because the $\left[\mathrm{Dmt}^{1}\right]$ DYN peptide was as active as the parent peptide in a GPI assay [66]. Similar results have been reported for the Phe ${ }^{1}$-DYN (1-11) peptide [67]. Unexpectedly, however, 27 possessed 3-fold greater affinity toward the ORL1 receptor, whereas 26 exhibited an order of magnitude decrease in ORL1 receptor affinity, indicating that $\mathrm{Dmp}^{4}$ modification in DYN peptides is detrimental to ORL1-receptor affinity. Simultaneous Dmp replacements in positions 1 and 4 (28) resulted in a two order of magnitude decrease in $\kappa$-receptor affinity and dramatically reduced GPI potency with loss of receptor selectivity. These results indicate that the $\mathrm{N}$ terminal phenolic hydroxyl group of the DYN peptide is not mandatory for $\kappa$-receptor binding but is critically important for receptor activation.

As shown in Table 4, Dmp ${ }^{1}$-NOC peptide (30) possessed high ORL1 receptor affinity comparable to the parent peptide NOC (1-13)- $\mathrm{NH}_{2}$. Interestingly, this analog exhibited improved affinity toward the three opioid receptors, with 5 - and 16-fold improved affinity for the $\kappa$ - and $\mu$-receptors, respectively, perhaps due to the effect of $\mathrm{Dmp}^{1}$, which can mimic $\mathrm{Tyr}^{1}$ in some opioid peptides without a substantial decrease in receptor affinity $[53,58]$. Dmp substitutions in positions 1 and 4 afforded 31 with a moderate decrease in affinity toward the ORL1 and opioid receptors, indicating that a Dmp residue in position 1 can compensate for the decrease caused by the Dmp ${ }^{4}$ substitution.

Substitution of the peptide with an artificial amino acid often improves metabolic stability, which is useful when conducting in vivo and in vitro studies. As shown in Table 7, Dmp ${ }^{1}$-substituted analogs 27 and $\mathbf{3 0}$ showed greater stability toward aminopeptidase M (AP-M) and rat brain synaptosomal enzymes compared to the parent peptides, which suggests the involvement of aminopeptidase(s) in the brain that breaks down these analogs as observed with intact NOC $[68,69]$ and DYN $[70,71]$. However, the stability of the Dmp ${ }^{4}$-substituted analogs (26 and 29) was similar to or somewhat less than that of the parent peptide toward rat brain enzymes. These results imply that a Dmp residue in 
TABLE 4: Receptor-binding affinity of DYN analogs and NOC analogs containing Dmp for opioid receptors and ORLl receptor.

\begin{tabular}{|c|c|c|c|c|c|c|}
\hline \multirow{3}{*}{ Peptides } & & \multicolumn{5}{|c|}{$\mathrm{IC}_{50} \pm \mathrm{SEM}(\mathrm{nM})$} \\
\hline & & \multirow{2}{*}{$\begin{array}{c}\text { ORL1 receptor } \\
{\left[{ }^{3} \mathrm{H}\right] \mathrm{NOC}^{\mathrm{a}}}\end{array}$} & \multicolumn{4}{|c|}{ Opioid receptor } \\
\hline & & & {$\left[{ }^{3} \mathrm{H}\right] \mathrm{U}-69593(\kappa)^{\mathrm{b}}$} & {$\left[{ }^{3} \mathrm{H}\right]$ DAMGO $(\mu)^{\mathrm{c}}$} & {$\left[{ }^{3} \mathrm{H}\right] \mathrm{DT}(\delta)^{\mathrm{c}}$} & $\kappa / \mu / \delta$ \\
\hline DYN(I-13)- $\mathrm{NH}_{2}$ & & $18.8 \pm 3.01$ & $0.162 \pm 0.049$ & $2.53 \pm 0.38$ & $6.49 \pm 1.11$ & $1 / 15.6 / 40.1$ \\
\hline$\left[\mathrm{Dmp}^{4}\right] \mathrm{DYN}(1-13)-\mathrm{NH}_{2}$ & $(26)$ & $188 \pm 18.2$ & $0.044 \pm 0.035$ & $22.4 \pm 10.2$ & $931 \pm 723$ & $1 / 509 / 21159$ \\
\hline$\left[\mathrm{Dmp}^{1}\right] \mathrm{DYN}(1-13)-\mathrm{NH}_{2}$ & $(27)$ & $6.60 \pm 0.952$ & $0056 \pm 0026$ & $16.4 \pm 2.35$ & $10.1 \pm 6.02$ & $1 / 293 / 180$ \\
\hline$\left[\mathrm{Dmp}^{1,4}\right] \mathrm{DYN}(1-13)-\mathrm{NH}_{2}$ & (28) & $51.5 \pm 1.62$ & $5.45 \pm 1.65$ & $251 \pm 56.3$ & $415 \pm 185$ & $1 / 46 / 76.1$ \\
\hline NOC & & $0.151 \pm 0.058$ & $643 \pm 218$ & $1540 \pm 601$ & $>10000$ & - \\
\hline $\mathrm{NOC}(1-13)-\mathrm{NH}_{2}$ & & $0.743 \pm 0.125$ & $193 \pm 54$ & $319 \pm 88$ & $>10000$ & - \\
\hline$\left[\mathrm{Dmp}^{4}\right] \mathrm{NOC}(1-13)-\mathrm{NH}_{2}$ & $(29)$ & $51.6 \pm 12.9$ & $299 \pm 63$ & $629 \pm 433$ & $>10000$ & - \\
\hline$\left[\mathrm{Dmp}^{1}\right] \mathrm{NOC}(1-13)-\mathrm{NH}_{2}$ & $(30)$ & $0.814 \pm 0.090$ & $38.8 \pm 16.7$ & $25.0 \pm 6.5$ & $292 \pm 61$ & - \\
\hline$\left[\mathrm{Dmp}^{1,4}\right] \mathrm{NOC}(1-13)-\mathrm{NH}_{2}$ & (31) & $21.3 \pm 3.2$ & $100 \pm 29$ & $56.8 \pm 12.3$ & $3407 \pm 990$ & - \\
\hline
\end{tabular}

${ }^{a}$ Using cell membrane expressing human ORL1 receptor in Hek-293 cells. ${ }^{b}$ Using guinea pig brain homogenate.

${ }^{\mathrm{c}}$ Using rat brain homogenate.

TABLE 5: GPI assay and opioid receptor preference of DYN analogs.

\begin{tabular}{|c|c|c|c|c|c|}
\hline \multirow{2}{*}{ Peptides } & & \multirow{2}{*}{$\mathrm{IC}_{50} \pm \mathrm{SEM}(\mathrm{nM})$} & \multicolumn{3}{|c|}{$K_{\mathrm{e}}(\mathrm{nM})$ value of receptor selective antagonist } \\
\hline & & & nor-BNI $(\kappa)$ & CTAP $(\mu)$ & $\mathrm{N}, \mathrm{N}(\mathrm{Me})_{2}$ Dmt-Tic-OH $(\delta)$ \\
\hline $\mathrm{DYN}(1-13)-\mathrm{NH}_{2}$ & & $3.14 \pm 1.13$ & 1.1 & 99 & 98 \\
\hline$\left[\mathrm{Dmp}^{4}\right] \mathrm{DYN}(\mathrm{I}-13)-\mathrm{NH}_{2}$ & (26) & $32.2 \pm 9.16$ & 0.63 & 108 & 198 \\
\hline$\left[\mathrm{Dmp}^{1}\right] \mathrm{DYN}(\mathrm{l}-13)-\mathrm{NH}_{2}$ & $(27)$ & $306 \pm 68$ & 10 & 115 & $>1000$ \\
\hline$\left[\mathrm{Dmp}^{1,4}\right] \mathrm{DYN}(1-13)-\mathrm{NH}_{2}$ & $(28)$ & $1341 \pm 303$ & 809 & 595 & $>100$ \\
\hline
\end{tabular}

position 4 offers no additional metabolic stability for either peptide and that endopeptidases play a major role in brain metabolism. A doubly Dmp-replaced NOC analog 31 also possessed no additional stability, whereas its counterpart DYN analog 28 possessed improved metabolic stability. Comparison of the metabolism of Dmp-containing NOC and DYN analogs suggested that the NOC peptides generally are more susceptible to aminopeptidases and endopeptidases although other results in human blood have been reported [71].

\section{Conclusions}

The usefulness of the artificial amino acid residue Dmp was investigated as an aromatic amino acid surrogate for opioid peptides and related peptides, including ENK, DM, YRFB, DT, EM2, DYN, and NOC peptides. In most opioid peptides, substitution of $\mathrm{Phe}^{3}$ by Dmp produced analogs with improved receptor-binding affinity and selectivity, for example, $\left[\mathrm{Dmp}^{3}\right] \mathrm{EM} 2(\mathbf{1 4}),\left[\mathrm{Dmp}^{3}\right] \mathrm{DM}(\mathbf{1 8}),\left[\mathrm{Dmp}^{3}\right] \mathrm{DT}$ (20), and $\left[\mathrm{Dmp}^{3}\right]$ YRFB (22), while substitution by the D-enantiomer resulted in decreased receptor affinity and selectivity. A small analog [D-Dmp ${ }^{3}$ ] YRFB (23) was the only exception because it possessed high $\mu$ affinity similar to the parent peptide. However, Dmp-substitution in position 4 produced analogs with markedly reduced receptor affinity and selectivity, for example, $\left[\mathrm{Dmp}^{4}\right] \mathrm{ENK}(\mathbf{1 0}),\left[\mathrm{Dmp}^{4}\right] \mathrm{EM} 2$
(16), and $\left[\mathrm{Dmp}^{4}\right] \mathrm{NOC}(1-13)-\mathrm{NH}_{2}$ (29), while their D$\mathrm{Dmp}^{4}$-analogs were almost devoid of receptor affinity and opioid activity. [ $\left.\mathrm{Dmp}^{4}\right] \mathrm{DYN}(1-13)-\mathrm{NH}_{2}$ (26) exceptionally possessed significantly improved receptor affinity for the $\kappa$-opioid receptor and outstanding $\kappa$-receptor selectivity. Interestingly, replacement of $\mathrm{Tyr}^{1}$ by $\mathrm{Dmp}$ residue produced analogs with equipotent or only slightly reduced receptor affinity and in vitro bioactivity, for example, [Dmp $\left.{ }^{1}\right]$ EM2 (38), [Dmp $\left.{ }^{1}\right]$ DT (34), [Dmp $\left.{ }^{1}\right]$ YRFB (24), and $\left[\mathrm{Dmp}^{1}\right] \mathrm{DYN}(1-13)-\mathrm{NH}_{2}$ (27). Thus, Dmp is also a useful surrogate for the $\mathrm{N}$-terminal Tyr residue in opioid peptides despite the lack of a phenolic hydroxyl group, which has been considered to be indispensable for opioid activity. The Dmp ${ }^{1}$-substituted analogs are superior to Dmt ${ }^{1}$-substituted analogs in opioid receptor selectivity because the $\mathrm{Dmt}^{1}$ analogs generally possess outstandingly high affinity to opioid receptors but poor receptor selectivity. These results demonstrate that Dmp is very useful as an aromatic amino acid surrogate in opioid peptides and may be applicable to other biologically active peptides for the development of novel peptide mimetics with high receptor specificity.

\section{Abbreviations}

Dmp: $\quad 2^{\prime}, 6^{\prime}$-Dimethylphenylalanine

Dmt: $\quad 2^{\prime}, 6^{\prime}$-Dimethyltyrosine

DAMGO: [D-Ala ${ }^{2}, \mathrm{MePhe}^{4}, \mathrm{Gly}^{-\mathrm{ol}^{5}}$ ] enkephalin 


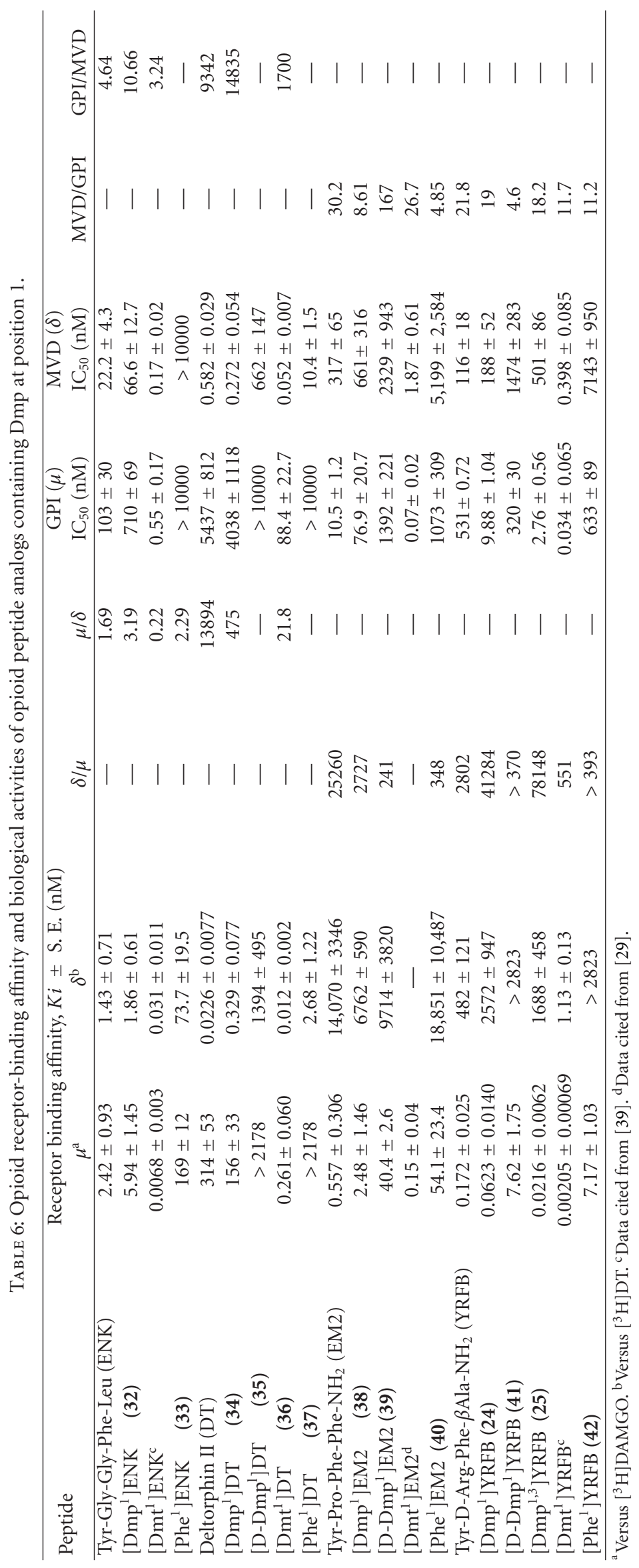


TABle 7: Comparison of stability of Dmp-containing peptides toward enzymatic degradation.

\begin{tabular}{|c|c|c|c|}
\hline \multirow{2}{*}{ Peptides } & & \multicolumn{2}{|c|}{ Half-life time $(\min )^{a}$} \\
\hline & & $\begin{array}{c}\text { Aminopeptidase } \\
\text { M }\end{array}$ & $\begin{array}{c}\text { Rat brain } \\
\text { homogenate }\end{array}$ \\
\hline DYN(I-13)- $\mathrm{NH}_{2}$ & & 15.5 & 435 \\
\hline$\left[\mathrm{Dmp}^{4}\right] \mathrm{DYN}(\mathrm{l}-13)-\mathrm{NH}_{2}$ & (26) & $\mathrm{NT}^{\mathrm{b}}$ & 315 \\
\hline$\left[\mathrm{Dmp}^{1}\right] \mathrm{DYN}(1-13)-\mathrm{NH}_{2}$ & $(27)$ & $>30$ & 577 \\
\hline $\begin{array}{l}{\left[\mathrm{Dmp}^{1,4}\right] \mathrm{DYN}(1-13)-} \\
\mathrm{NH}_{2} \quad(\mathbf{2 8})\end{array}$ & & $\mathrm{NT}^{\mathrm{b}}$ & 770 \\
\hline $\operatorname{NOC}(1-13)-\mathrm{NH}_{2}$ & & 12 & 41.5 \\
\hline$\left[\mathrm{Dmp}^{4}\right] \mathrm{NOC}(1-13)-\mathrm{NH}_{2}$ & (29) & $\mathrm{NT}^{\mathrm{b}}$ & 33.6 \\
\hline$\left[\mathrm{Dmp}^{1}\right] \mathrm{NOC}(1-13)-\mathrm{NH}_{2}$ & (30) & 28 & 60.3 \\
\hline $\begin{array}{l}{\left[\mathrm{Dmp}^{1,4}\right] \mathrm{NOC}(1-13)-} \\
\mathrm{NH}_{2}\end{array}$ & & $\mathrm{NT}^{\mathrm{b}}$ & 27.1 \\
\hline Met-enkephalin & & $<5$ & 8.5 \\
\hline
\end{tabular}

${ }^{\mathrm{a}}$ Determined by HPLC. ${ }^{\mathrm{b}}$ Not tested.

ENK: Leu-enkephalin, Tyr-Gly-Gly-Phe-Leu

DM: Dermorphin Tyr-D-Ala-Phe-Gly-Tyr-Pro-Ser- $\mathrm{NH}_{2}$

DT: $\quad\left[\mathrm{D}-\mathrm{Ala}^{2}\right]$ deltorphin II, Tyr-D-Ala-Phe-Glu-Val-Val-Gly- $\mathrm{NH}_{2}$

YRFB: Tyr-D-Arg-Phe- $\beta$ Ala- $\mathrm{NH}_{2}$

EM2: Endomorphin 2, Tyr-Pro-Phe-Phe- $\mathrm{NH}_{2}$

CTAP: D-Phe-c[Cys-Tyr-D-Trp-Arg-Thr-Pen]-Thr$\mathrm{NH}_{2}$

NOC: Nociceptin/orphanin FQ

DYN: Dynorphin A

ORL1: Opioid receptor-like 1

AP-M: Aminopeptidase M

GPI: Guinea pig ileum

MVD: Mouse vas deferens.

\section{References}

[1] T. Reisine, "Neurotransmitter receptors V. Opiate receptors," Neuropharmacology, vol. 34, no. 5, pp. 463-472, 1995.

[2] B. N. Dhawan, F. Cesselin, R. Raghubir et al., "International Union of Pharmacology. XII. Classification of opioid receptors," Pharmacological Reviews, vol. 48, no. 4, pp. 567-592, 1996.

[3] P. A. Zaki, E. J. Bilsky, T. W. Vanderah, J. Lai, C. J. Evans, and F. Porreca, "Opioid receptor types and subtypes: the $\delta$ receptor as a model," Annual Review of Pharmacology and Toxicology, vol. 36, pp. 379-401, 1996.

[4] R. J. Bodnar, "Endogenous opiates and behavior: 2010," Peptides, vol. 32, no. 12, pp. 2522-2552, 2011.

[5] J. Hughes, T. W. Smith, and H. W. Kosterlitz, "Identification of two related pentapeptides from the brain with potent opiate agonist activity," Nature, vol. 258, no. 5536, pp. 577-579, 1975.

[6] J. E. Zadina, L. Hackler, L. J. Ge, and A. J. Kastin, "A potent and selective endogenous agonist for the $\mu$-opiate receptor," Nature, vol. 386, no. 6624, pp. 499-502, 1997.

[7] A. Goldstein, The Peptides: Analysis, Synthesis, Biology, S. Udenfriend and J. Meienhofer, Eds., Academic Press, New York, NY, USA, 1984.
[8] P. C. Montecucchi, R. De Castiglione, S. Piani, L. Gozzini, and V. Erspamer, "Amino acid composition and sequence of dermorphin, a novel opiate-like peptide from the skin of Phyllomedusa sauvagei," International Journal of Peptide and Protein Research, vol. 17, no. 3, pp. 275-283, 1981.

[9] V. Erspamer, P. Melchiorri, G. Falconieri-Erspamer et al., "Deltrophins: a family of naturally occurring peptides with high affinity and selectivity for $\delta$ opioid binding sites," Proceedings of the National Academy of Sciences of the United States of America, vol. 86, no. 13, pp. 5188-5192, 1989.

[10] J. R. Bunzow, C. Saez, M. Mortrud et al., "Molecular cloning and tissue distribution of a putative member of the rat opioid receptor gene family that is not a $\mu, \delta$ or $\kappa$ opioid receptor type," FEBS Letters, vol. 347, no. 2-3, pp. 284-288, 1994.

[11] J. C. Meunier, C. Mollereau, L. Toll et al., "Isolation and structure of the endogenous agonist of opioid receptor-like ORL1 receptor," Nature, vol. 377, no. 6549, pp. 532-535, 1995.

[12] R. K. Reinscheid, H. P. Nothacker, A. Bourson et al., "Orphanin FQ: a neuropeptide that activates an opioidlike G protein-coupled receptor," Science, vol. 270, no. 5237, pp. 792794, 1995.

[13] J.-C. Meunier, "Nociceptin/orphanin FQ and the opioid receptor-like ORL1 receptor," European Journal of Pharmacology, vol. 340, no. 1, pp. 1-15, 1997.

[14] R. K. Reinscheid, A. Ardati, F. J. Monsma, and O. Civelli, "Structure-activity relationship studies on the novel neuropeptide orphanin FQ," Journal of Biological Chemistry, vol. 271, no. 24, pp. 14163-14168, 1996.

[15] E. Okuda-Ashitaka, S. Tachibana, T. Houtani et al., "Identification and characterization of an endogenous ligand for opioid receptor homologue ROR-C: its involvement in allodynic response to innocuous stimulus," Molecular Brain Research, vol. 43, no. 1-2, pp. 96-104, 1996.

[16] C. T. Dooley and R. A. Houghten, "Orphanin FQ: receptor binding and analog structure activity relationships in rat brain," Life Sciences, vol. 59, no. 1, pp. PL23-PL29, 1996.

[17] R. Guerrini, G. CalO', A. Rizzi et al., "Address and message sequences for the nociceptin receptor: a structure- activity study of nociceptin-(1-13)-peptide amide," Journal of Medicinal Chemistry, vol. 40, no. 12, pp. 1789-1793, 1997.

[18] V. J. Hruby and R. S. Agnes, "Conformation-activity relationships of opioid peptides with selective activities at opioid receptors," Biopolymers, vol. 51, no. 6, pp. 391-410, 1999.

[19] Y. Shimohigashi, R. Hatano, T. Fujita et al., "Sensitivity of opioid receptor-like receptor ORL1 for chemical modification on nociceptin, a naturally occurring nociceptive peptide," Journal of Biological Chemistry, vol. 271, no. 39, pp. 2364223645, 1996.

[20] R. K. Reinscheid, J. Higelin, R. A. Henningsen, F. J. Monsma, and O. Civelli, "Structures that delineate orphanin FQ and dynorphin A pharmacological selectivities," Journal of Biological Chemistry, vol. 273, no. 3, pp. 1490-1495, 1998.

[21] V. J. Hruby and C. A. Gehrig, "Recent developments in the design of receptor specific opioid peptides," Medicinal Research Reviews, vol. 9, no. 3, pp. 343-401, 1989.

[22] D. W. Hansen Jr, R. H. Mazur, and M. Clare, "The synthesis and SAR of orally active enkephalin analogs with modified $\mathrm{N}$ terminal tyrosine residue," in Peptides: Structure and Function, C. M. Deber, V. J. Hruby, and K. D. Kopple, Eds., pp. 491-494, Pierce Chemical, Rockford, Ill, USA, 1985.

[23] N. S. Chandrakumar, P. K. Yonan, A. Stapelfeld et al., "Preparation and opioid activity of analogues of the analgesic 
dipeptide 2,6-dimethyl-L-tyrosyl-N-(3-phenylpropyl)-D-alaninamide," Journal of Medicinal Chemistry, vol. 35, no. 2, pp. 223-233, 1992.

[24] D. W. Hansen Jr., A. Stapelfeld, M. A. Savage et al., "Systemic analgesic activity and $\delta$-opioid selectivity in [2,6-dimethylTyr $^{1}$, D-Pen ${ }^{2}$, D-Pen ${ }^{5}$ enkephalin," Journal of Medicinal Chemistry, vol. 35, no. 4, pp. 684-687, 1992.

[25] B. S. Pitzele, R. W. Hamilton, K. D. Kudla et al., "Enkephalin analogs as systemically active antinociceptive agents: $\mathrm{O}-$ and $\mathrm{N}$-alkylated derivatives of the dipeptide amide L-2,6-dimethyltyrosyl-N-(3-phenylpropyl)-D-alaninamide," Journal of Medicinal Chemistry, vol. 37, no. 7, pp. 888-896, 1994.

[26] P. W. Schiller, G. Weltrowska, R. Schmidt et al., "Four different types of opioid peptides with mixed mu agonist/delta antagonist properties," Analgesia, vol. 1, pp. 703-706, 1995.

[27] S. Salvadori, M. Attila, G. Balboni et al., "Delta opioidmimetic antagonists: prototypes for designing a new generation of ultraselective opioid peptides.," Molecular Medicine, vol. 1, no. 6, pp. 678-689, 1995.

[28] R. Guerrini, A. Capasso, L. Sorrentino et al., "Opioid receptor selectivity alteration by single residue replacement: synthesis and activity profile of [Dmt $\left.{ }^{1}\right]$ deltorphin B," European Journal of Pharmacology, vol. 302, no. 1-3, pp. 37-42, 1996.

[29] Y. Okada, Y. Fujita, T. Motoyama et al., "Structural studies of $\left[2^{\prime}, 6^{\prime}\right.$-dimethyl-L-tyrosine $\left.{ }^{1}\right]$ endomorphin-2 analogues: enhanced activity and cis orientation of the Dmt-Pro amide bond," Bioorganic and Medicinal Chemistry, vol. 11, no. 9, pp. 1983-1994, 2003.

[30] C. Wang, I. J. McFadyen, J. R. Traynor, and H. I. Mosberg, "Design of a high affinity peptidomimetic opioid agonist from peptide pharmacophore models," Bioorganic and Medicinal Chemistry Letters, vol. 8, no. 19, pp. 2685-2688, 1998.

[31] A. Capasso, R. Guerrini, G. Balboni et al., "Dmt-Tic-OH a highly selective and potent delta-opioid dipeptide receptor antagonist after systemic administration in the mouse.," Life sciences, vol. 59, no. 8, pp. PL93-PL98, 1996.

[32] S. D. Bryant, S. Salvadori, P. S. Cooper, and L. H. Lazarus, "New $\delta$-opioid antagonists as pharmacological probes," Trends in Pharmacological Sciences, vol. 19, pp. 42-46, 1999.

[33] S. Salvadori, R. Guerrini, G. Balboni et al., "Further studies on the Dmt-Tic pharmacophore: hydrophobic substituents at the C-terminus endow $\delta$ antagonists to manifest $\mu$ agonism or $\mu$ antagonism," Journal of Medicinal Chemistry, vol. 42, no. 24, pp. 5010-5019, 1999.

[34] P. W. Schiller, R. Schmidt, G. Weltrowska et al., "Conformationally constrained opioid peptide analogs with novel activity profiles," Letters in Peptide Science, vol. 5, no. 2-3, pp. 209-214, 1998.

[35] P. W. Schiller, M. E. Fundytus, L. Merovitz et al., "The opioid $\mu$ agonist $/ \delta$ antagonist $\mathrm{DIPP}-\mathrm{NH}_{2}[\Psi]$ produces a potent analgesic effect, no physical dependence, and less tolerance than morphine in rats," Journal of Medicinal Chemistry, vol. 42, no. 18, pp. 3520-3526, 1999.

[36] Y. Sasaki, T. Suto, A. Ambo, H. Ouchi, and Y. Yamamoto, "Biological properties of opioid peptides replacing Tyr at position 1 by 2,6-dimethyl-Tyr," Chemical and Pharmaceutical Bulletin, vol. 47, no. 10, pp. 1506-1509, 1999.

[37] P. Majer, J. Slaninova, and M. Lebl, "Synthesis of methylated phenylalanines via hydrogenolysis of corresponding 1,2,3,4tetrahydroisoquinoline-3-carboxylic acids. Synthesis and biological activity of oxytocin analogs with methylated phenylalanines in position 2," International Journal of Peptide and Protein Research, vol. 43, no. 1, pp. 62-68, 1994.
[38] S. Sagan, H. Josien, P. Karoyan, A. Brunissen, G. Chassaing, and S. Lavielle, "Tachykinin NK-1 receptor probed with constrained analogues of substance P," Bioorganic and Medicinal Chemistry, vol. 4, no. 12, pp. 2167-2178, 1996.

[39] Y. Sasaki, M. Hirabuki, A. Ambo, H. Ouchi, and Y. Yamamoto, "Enkephalin analogues with 2',6'-dimethylphenylalanine replacing phenylalanine in position 4," Bioorganic and Medicinal Chemistry Letters, vol. 11, no. 3, pp. 327-329, 2001.

[40] Y. Yamamoto, H. Ouchi, T. Tanaka, and Y. Morita, "Direct introduction of acyl and ethoxycarbonyl groups into pyrimidine ring through the trimethylstannyl derivatives," Heterocycles, vol. 41, no. 6, pp. 1275-1290, 1995.

[41] A. Ohno, A. Tsutsumi, N. Yamazaki, M. Okamura, Y. Mikata, and M. Fujii, "NAD $(\mathrm{P})^{+}-\mathrm{NAD}(\mathrm{P}) \mathrm{H}$ Models. 87. Nonsteric Stereochemistry Controlled by a Carbonyl Dipole," Bulletin of the Chemical Society of Japan, vol. 69, no. 6, pp. 1679-1685, 1996.

[42] J. H. Dygos, E. E. Yonan, M. G. Scaros et al., "A convenient asymmetric synthesis of the unnatural amino acid 2,6dimethyl-L-tyrosine," Synthesis, no. 8, pp. 741-743, 1992.

[43] G. Toth, M. Lebl, and V. J. Hruby, "Chiral TLC separation of phenylalanine and tyrosine derivatives," Journal of Chromatography, vol. 504, pp. 450-455, 1990.

[44] T. Li, K. Shiotani, A. Miyazaki et al., "Bifunctional $\left[2^{\prime}, 6^{\prime}-\right.$ dimethyl-L-tyrosine ${ }^{1}$ ] endomorphin-2 analogues substituted at position 3 with alkylated phenylalanine derivatives yield potent mixed $\mu$-agonist $/ \delta$-antagonist and dual $\mu$-agonist $/ \delta$ agonist opioid ligands," Journal of Medicinal Chemistry, vol. 50, no. 12, pp. 2753-2766, 2007.

[45] Y. Sasaki, A. Ambo, and K. Suzuki, "[D-Ala²]deltorphin II analogs with high affinity and selectivity for delta-opioid receptor," Biochemical and Biophysical Research Communications, vol. 180, no. 2, pp. 822-827, 1991.

[46] Y. Sasaki, A. Ambo, K. Midorikawa, and K. Suzuki, "Solidphase synthesis and opioid activities of [D-Ala $\left.{ }^{2}\right]$ deltorphin II analogs," Chemical and Pharmaceutical Bulletin, vol. 41, no. 8, pp. 1391-1394, 1993.

[47] F. M. Leslie, "Methods used for the study of opioid receptors," Pharmacological Reviews, vol. 39, no. 3, pp. 197-249, 1987.

[48] A. Capasso, P. Amodeo, G. Balboni et al., "Design of $\mu$ selective opioid dipeptide antagonists," FEBS Letters, vol. 417, no. 1, pp. 141-144, 1997.

[49] Y. Sasaki, A. Sasaki, H. Niizuma, H. Goto, and A. Ambo, "Endomorphin 2 analogues containing Dmp residue as an aromatic amino acid surrogate with high $\mu$-opioid receptor affinity and selectivity," Bioorganic and Medicinal Chemistry, vol. 11, no. 5, pp. 675-678, 2003.

[50] Y. Okada, A. Fukumizu, M. Takahashi et al., "Synthesis of stereoisomeric analogues of endomorphin-2, H-Tyr-ProPhe-Phe- $\mathrm{NH}_{2}$, and examination of their opioid receptor binding activities and solution conformation," Biochemical and Biophysical Research Communications, vol. 276, no. 1, pp. 7-11, 2000.

[51] J. T. Pelton, W. Kazmierski, K. Gulya, H. I. Yamamura, and V. J. Hruby, "Design and synthesis of conformationally constrained somatostatin analogues with high potency and specificity for $\mu$ opioid receptors," Journal of Medicinal Chemistry, vol. 29, no. 11, pp. 2370-2375, 1986.

[52] A. Ambo, H. Murase, H. Niizuma, H. Ouchi, Y. Yamamoto, and Y. Sasaki, "Dermorphin and deltorphin heptapeptide analogues: replacement of Phe residue by Dmp greatly improves opioid receptor affinity and selectivity," Bioorganic and Medicinal Chemistry Letters, vol. 12, no. 6, pp. 879-881, 2002. 
[53] Y. Sasaki, A. Ambo, and K. Suzuki, "Studies on analgesic oligopeptides. VII. Solid phase synthesis and biological properties of Tyr-D-Arg-Phe- $\beta$ Ala- $\mathrm{NH}_{2}$ and its fluorinated aromatic amino acid derivatives," Chemical and Pharmaceutical Bulletin, vol. 39, no. 9, pp. 2316-2318, 1991.

[54] A. Ambo, H. Niizuma, A. Sasaki, H. Kohara, and Y. Sasaki, "Dermorphin tetrapeptide analogues with 2',6'dimethylphenylalanine (Dmp) substituted for aromatic amino acids have high $\mu$ opioid receptor binding and biological activities," Bioorganic and Medicinal Chemistry Letters, vol. 13, no. 7, pp. 1269-1272, 2003.

[55] Y. Sasaki, S. Kawano, H. Kohara, H. Watanabe, and A. Ambo, "ORL1 and opioid receptor preferences of nociceptin and dynorphin A analogues with Dmp substituted for N-terminal aromatic residues," Bioorganic and Medicinal Chemistry, vol. 14, no. 7, pp. 2433-2437, 2006.

[56] C. M. Topham, L. Mouledous, G. Poda, B. Maigret, and J. C. Meunier, "Molecular modelling of the ORL1 receptor and its complex with nociceptin," Protein Engineering, vol. 11, no. 12, pp. 1163-1179, 1998.

[57] Y. Sasaki, A. Sasaki, T. Ariizumi et al., " 2 ', 6 'dimethylphenylalanine (Dmp) can mimic the N-terminal Tyr in opioid peptides," Biological and Pharmaceutical Bulletin, vol. 27, no. 2, pp. 244-247, 2004.

[58] R. Schmidt, D. Menard, C. Mrestani-Klaus, N. N. Chung, C. Lemieux, and P. W. Schiller, "Structural modifications of the N-terminal tetrapeptide segment of [D-Ala $\left.{ }^{2}\right]$ Deltorphin I: effects on opioid receptor affinities and activities in vitro and on antinociceptive potency," Peptides, vol. 18, no. 10, pp. 1615$1621,1997$.

[59] J. T. Pelton, W. Kazmierski, K. Gulya, H. I. Yamamura, and V. J. Hruby, "Design and synthesis of conformationally constrained somatostatin analogues with high potency and specificity for $\mu$ opioid receptors," Journal of Medicinal Chemistry, vol. 29, no. 11, pp. 2370-2375, 1986.

[60] K. Gulya, J. T. Pelton, V. J. Hruby, and H. I. Yamamura, "Cyclic somatostatin octapeptide analogues with high affinity and selectivity toward mu opioid receptors," Life Sciences, vol. 38, no. 24, pp. 2221-2229, 1986.

[61] H. I. Mosberg, J. C. Ho, and K. Sobczyk-Kojiro, "A high affinity, Mu-opioid receptor-selective enkephalin analogue lacking an N-terminal tyrosine," Bioorganic and Medicinal Chemistry Letters, vol. 8, no. 19, pp. 2681-2684, 1998.

[62] I. J. McFadyen, K. Sobczyk-Kojiro, M. J. Schaefer et al., "Tetrapeptide derivatives of $\left[\mathrm{D}-\mathrm{Pen}^{2}, \mathrm{D}-\mathrm{Pen}^{5}\right]$-enkephalin (DPDPE) lacking an $\mathrm{N}$-terminal tyrosine residue are agonists at the $\mu$-opioid receptor," Journal of Pharmacology and Experimental Therapeutics, vol. 295, no. 3, pp. 960-966, 2000.

[63] J. E. Burden, P. Davis, F. Porreca, and A. F. Spatola, "Synthesis and biological activities of position one and three transposed analogs of the opioid peptide YKFA," Bioorganic and Medicinal Chemistry Letters, vol. 9, no. 24, pp. 3441-3446, 1999.

[64] N. S. Chandrakumar, A. Stapelfeld, P. M. Beardsley et al., "Analogs of the $\delta$ opioid receptor selective cyclic peptide [2-D-penicillamine,5-D-penicillamine]-enkephalin: $\quad 2^{\prime}, 6^{\prime}$ Dimethyltyrosine and $\mathrm{Gly}^{3}-\mathrm{Phe}^{4}$ amide bond isostere substitutions," Journal of Medicinal Chemistry, vol. 35, no. 16, pp. 2928-2938, 1992.

[65] L. H. Lazarus, S. D. Bryant, P. S. Cooper, and S. Salvadori, "What peptides these deltorphins be," Progress in Neurobiology, vol. 57, no. 4, pp. 377-420, 1999.

[66] Y. Lu, T. M. D. Nguyen, G. Weltrowska et al., " $\left[2^{\prime}, 6^{\prime}-\right.$ dimethyltyrosine] dynorphin $\mathrm{A}(1-11)-\mathrm{NH}_{2}$ analogues lacking an N-terminal amino group: potent and selective $\kappa$ opioid antagonists," Journal of Medicinal Chemistry, vol. 44, no. 19, pp. 3048-3053, 2001.

[67] A. M. Kawasaki, R. J. Knapp, A. Walton et al., "Syntheses, opioid binding affinities, and potencies of dynorphin A analogues substituted in positions 1, 6, 7, 8 and 10," International Journal of Peptide and Protein Research, vol. 42, no. 5, pp. 411-419, 1993.

[68] J. Yu, B. T. Chait, L. Toll, and M. J. Kreek, "Nociception in vitro biotransformation in human blood," Peptides, vol. 17, no. 5, pp. 873-876, 1996.

[69] J. L. Montiel, F. Cornille, B. P. Roques, and F. Noble, "Nociceptin/orphanin FQ metabolism: role of aminopeptidase and endopeptidase 24.15," Journal of Neurochemistry, vol. 68, no. 1, pp. 354-361, 1997.

[70] J.-P. Meyer, T. J. Gillespie, V. J. Hruby, and T. P. Davis, "In vitro stability of some reduced peptide bond pseudopeptide analogs of dynorphin A," Peptides, vol. 16, no. 7, pp. 1215-1219, 1995.

[71] J. Z. Chou, B. T. Chait, R. Wang, and M. J. Kreek, "Differential biotransformation of dynorphin $\mathrm{A}(1-17)$ and dynorphin $\mathrm{A}(1-$ 13) peptides in human blood, ex vivo," Peptides, vol. 17, no. 6, pp. 983-990, 1996. 


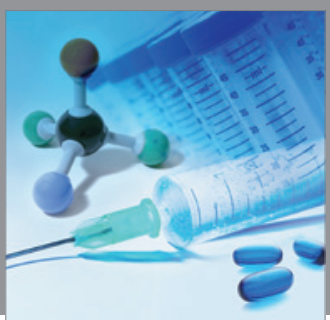

International Journal of

Medicinal Chemistry

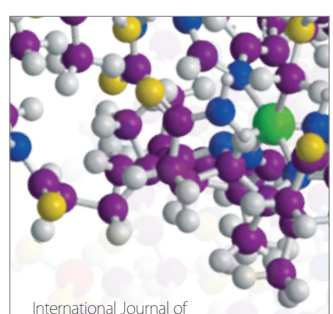

Carbohydrate Chemistry

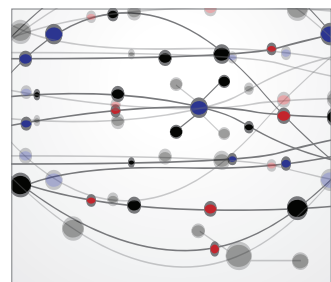

The Scientific World Journal
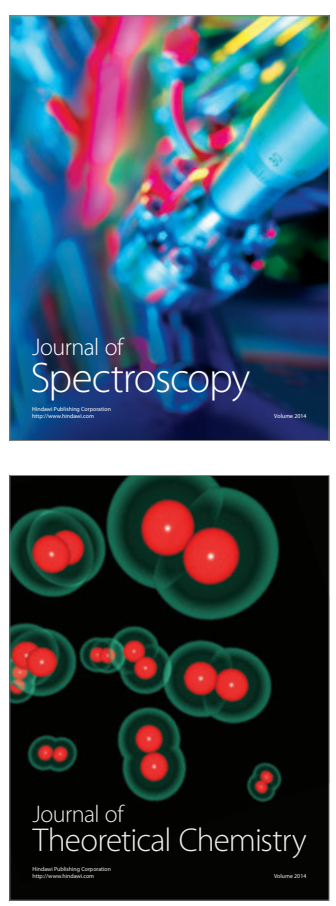
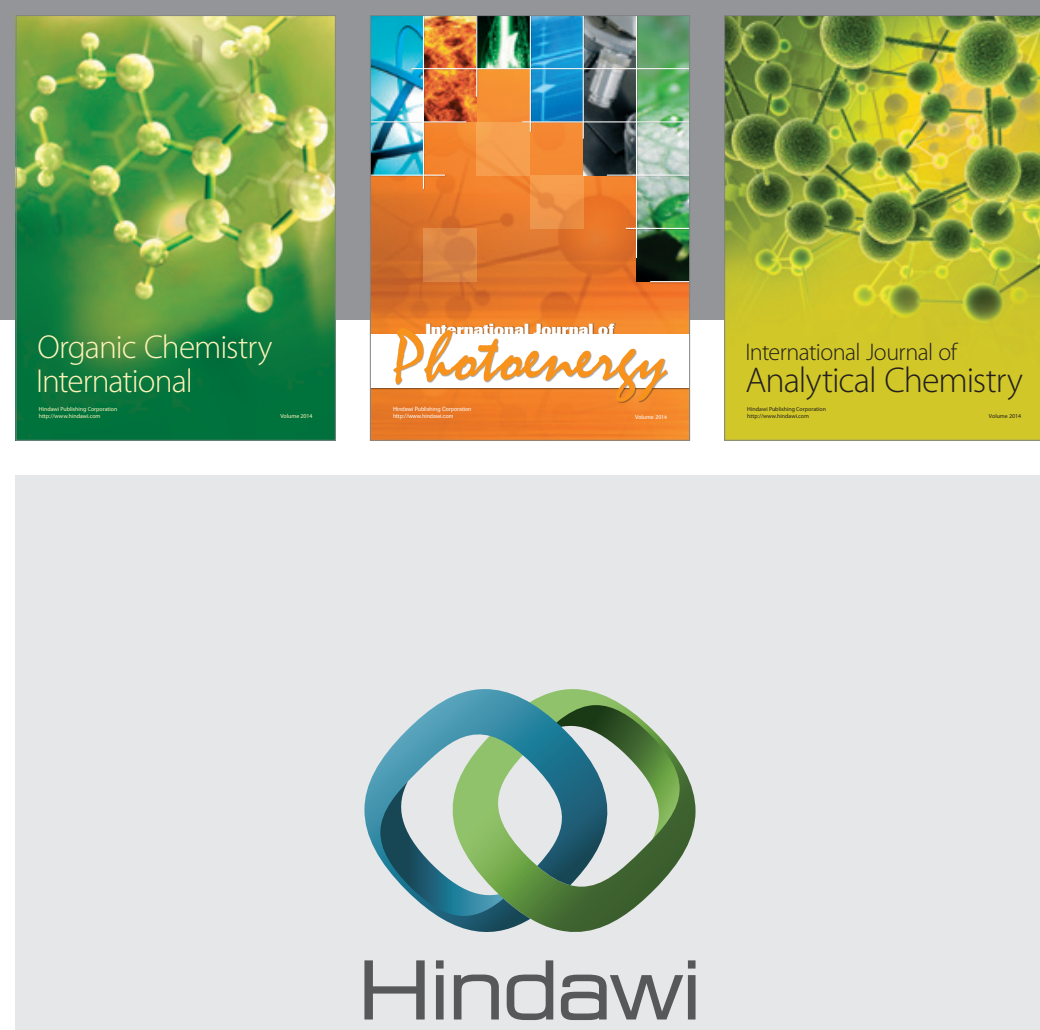

Submit your manuscripts at

http://www.hindawi.com
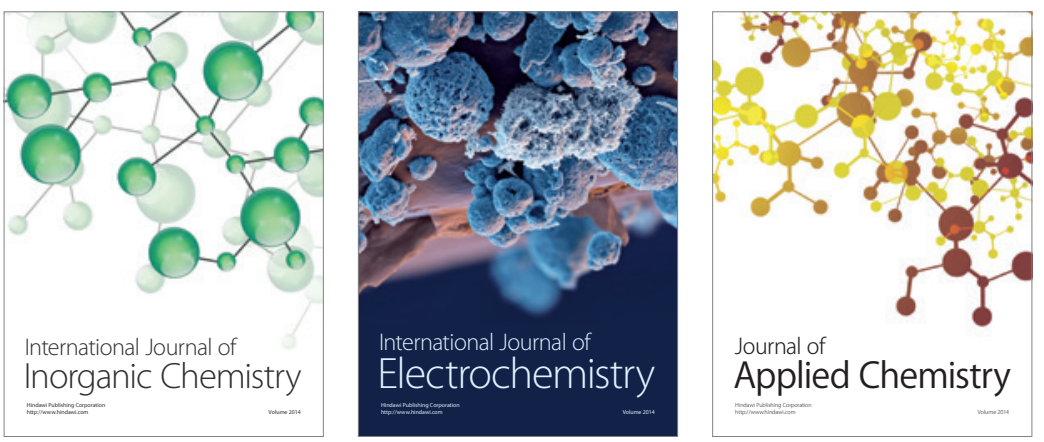

Journal of

Applied Chemistry
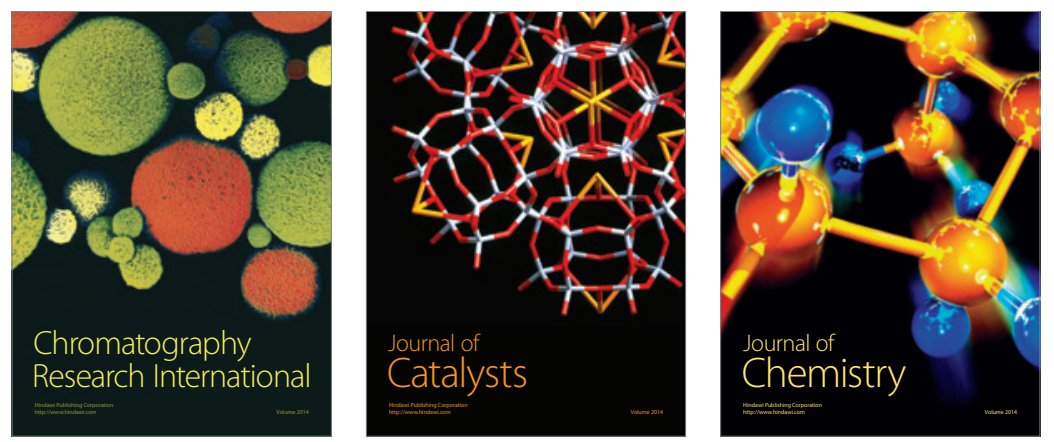
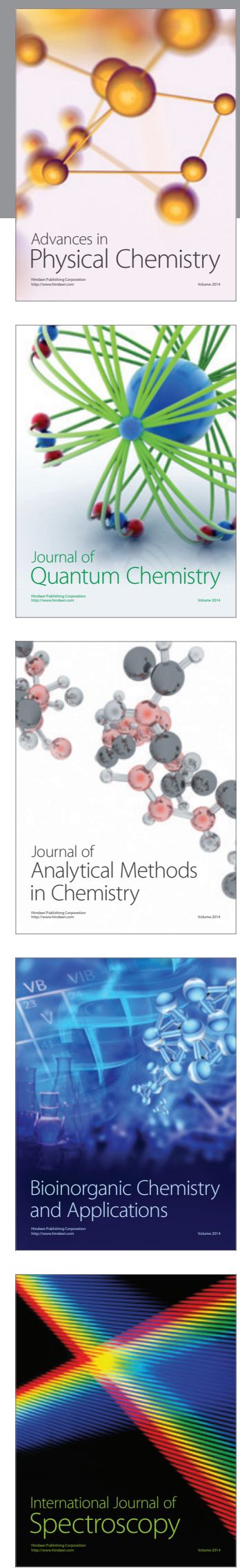